\title{
The Odd Future Participle at Pol. Phil. XIII: Reassessing the Authenticity and Unity of Polycarp's Letter to the Philippians
}

\author{
Otto Linderborg \\ Postdoctoral Researcher (externally funded), Mid Sweden University, \\ Faculty of Human Sciences, Department of Humanities and Social Sciences, \\ Sundsvall, Sweden \\ otto.linderborg@miun.se \\ Viktor Johansson \\ Master Student, Department of Linguistics and Philology, \\ Faculty of Languages, Uppsala University; Department of Archaeology \\ and Ancient History, Faculty of Arts, Uppsala University; Department \\ of Languages and Literatures, Faculty of Humanities, University \\ of Gothenburg, Uppsala, Sweden \\ Viktor.Johansson.7113@student.uu.se
}

\begin{abstract}
The Letter to the Philippians is the sole surviving work of the early Christian bishop and martyr, Polycarp of Smyrna. Ever since the 17th century scholars have contested the authenticity and unity of the letter without reaching a settlement. However, new linguistic evidence allows for a reassessment of the controversy. The future participle $\pi \rho \varepsilon \sigma \beta \varepsilon v \dot{\sigma} \sigma o v \tau \alpha$ at Pol. Phil. XIII.1 is one of a mere four occurrences of FPs in the entire corpus of the Apostolic Fathers, and the use of the FP is exceedingly rare among lowregister Judeo-Christian texts in general. The statistical analysis over a wide range of Ancient Greek literary texts conducted in this paper lends support to the conclusion that Pol. Phil. is a uniform text with a spurious interpolation in the form of the bulk of chapter XIII.
\end{abstract}

\section{Keywords}

Patristics - Apostolic Fathers - Polycarp

(C) OTTO LINDERBORG AND VIKTOR JOHANSSON, 2021 | DOI:10.1163/15700720-12341485

This is an open access article distributed under the terms of the COCB BY 4 olicense. Brill, com04/26/2023 09:50:26AM 
During his lifetime, Polycarp held a position as bishop in the Christian congregation of Smyrna in the Roman province of Asia, and it was here that he - around 16o CE - also met his death as a martyr. According to the ancient testimony of his martyrdom, Polycarp was first publicly denounced as 'the teacher of impiety' ( $\delta$ $\hat{\jmath} \varsigma \alpha \sigma \varepsilon \beta \varepsilon i \alpha \varsigma \delta 1 \delta \dot{\alpha} \sigma x \alpha \lambda \circ \varsigma)$ ), 'the father of the Christians'

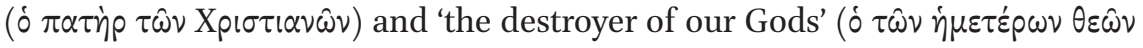

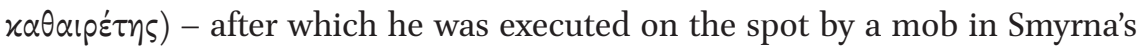
stadium. ${ }^{1}$ The extant epistle ascribed to Polycarp forms - alongside the seven letters of Ignatius of Antioch and the two of Clement of Rome - the kernel of those early Christian texts, which ever since the 17th century have been known under the name of 'the Apostolic Fathers'.

As to the scholarly works dealing specifically with the Letter to the Philippians, these have largely been dominated by questions revolving around the authenticity and unity of the text. The major obstacle for the presumption that the letter could indeed be both genuine and uniform, is that it seems to harbour contradictory accounts regarding another early church father and martyr: Ignatius of Antioch. The gist of the discrepancy is this: in the beginning and middle part of the Polycarpian letter, Ignatius' imprisonment and death (ca. 115 CE) are alluded to (Pol. Phil. I.1; IX). However, the text ends with an enquiry as to what exactly may have happened to Ignatius, alongside references to a collection of letters written by him (Pol. Phil. XIII.2). Indeed, Pol. XIII can even be read as if the author would still be unaware of Polycarp's death. ${ }^{3}$

In what follows, we provide the full text and our translations of the contentious passages. In this connection, it should be noted that since parts of the end of Polycarp's letter - i.e., Chapter X, XI, XII, the last sentence in Chapter XIII and the whole of the last Chapter XIV - have been preserved merely in Latin Mss; the original Greek can only be cited in its entirety for the first two passages.

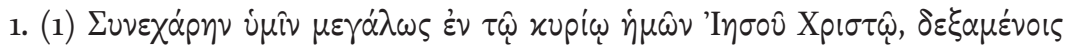

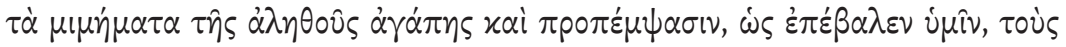

1 See Mart. Pol. XII-XVI. Supposedly, the crowd first tried to burn him alive on a pyre, but since the fire would not consume his body, they finished him off with a dagger - with the result that the fire was extinguished by the amount of blood pouring out from the wound.

2 The name derives from J.B. Cotelier's 1672 edition containing the works of the Apostolic Fathers. Cotelier described the writers edited by him as "Patres aevi $[. .$.$] qui temporibus apos-$ tolibus florerunt".

3 Note the present tense in the Latin sentence ending Pol. Phil. XIII.2: qui cum eo sunt: "those who are with him". 


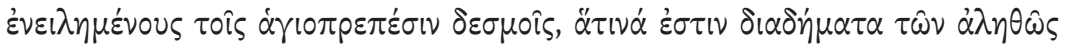

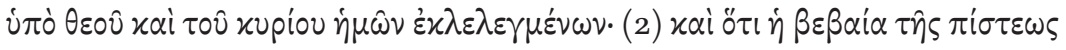

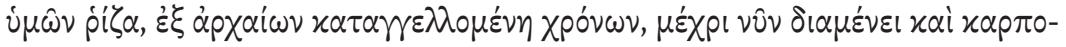

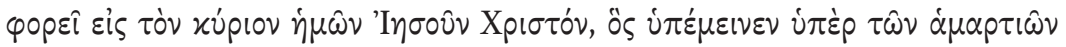

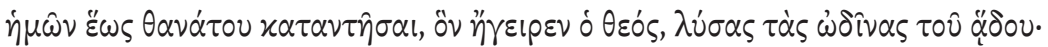

I greatly rejoiced with you in our Lord Jesus Christ, after you received the images of true love and - as is befitting you - escorted those who are enchained in chains proper for saints. Indeed, these chains are the crowns of those who are truly chosen by God, and by our Lord. [I also rejoiced with you] because the firm root of our faith, which has been proclaimed since days of old, remains until now, and bears fruit for our Lord Jesus Christ, who suffered death for our sins, and whom God resurrected - after having loosened the bonds of Hades.

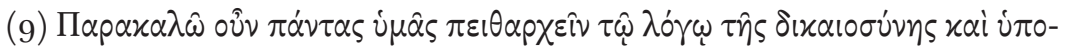

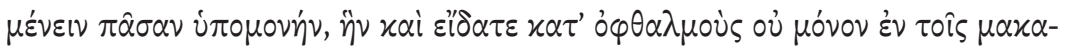

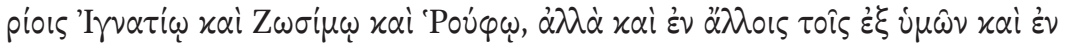

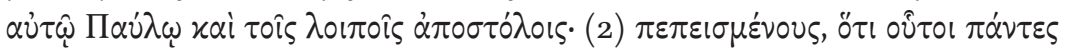

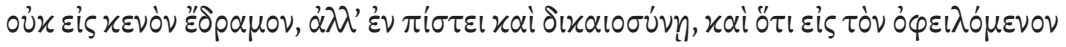

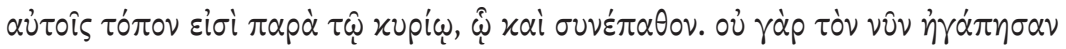

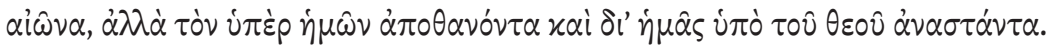

I therefore encourage you all to obey the word of righteousness and to endure all sufferings. This endurance you also witnessed with your own eyes, not only in the sufferings of the blessed Ignatius, Zosimos and Rufus, but also in those of others that belonged to you. You saw it also in Paul himself and the other apostles. Thus, you may be convinced that none of them suffered in vain, but in faith and righteousness, and that they now reside at their due place alongside the Lord - with whom they also suffered. For they did not love the present moment, but him who died for our sake, him whom God raised from the dead for our sake.

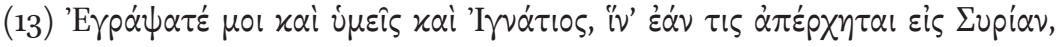

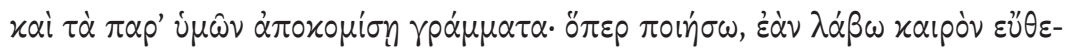

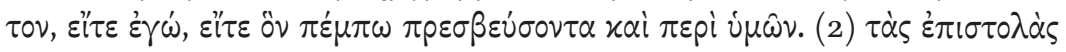

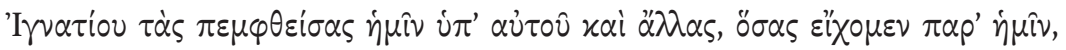

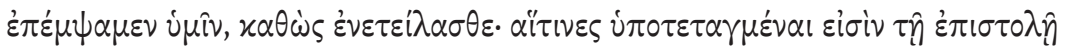

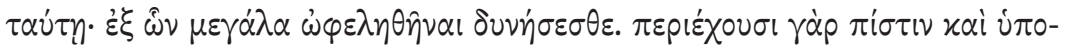
$\mu \circ v \dot{\eta} \nu$ xai $\pi \hat{\alpha} \sigma \alpha \nu$ oix Ignatio et de his, qui cum eo sunt, quod certius agnoveritis, significate. 
Both you and Ignatius wrote to me, in order that if anyone were to depart to Syria, he would also bring with him the letters sent by you. This I will also do, if only I get the opportunity; either I do it myself, or I send someone to act as a messenger also on your behalf. The epistles of Ignatius that were sent to us by him and others - as many as we possessed - we have sent to you, as was your request. You find these enclosed along with this letter. Indeed, you will greatly benefit from the content of these letters. For they contain faith, endurance and all edification that befits our Lord. Furthermore, as concerning Ignatius himself and those who are with him, what you have learned more certainly, do tell us.

It was J. Daillé who in 1666 initiated the debate on the ambiguities inherent in the above passages. He was the first one as well to offer a plausible solution to the controversy. Daille's argument was straightforward in that he claimed that Phil. XIII - the passage in which the writer reveals his ignorance of the fate of Ignatius - should be considered a spurious interpolation in an otherwise authentic letter. ${ }^{4}$ Against this view, J. Pearson suggested in 1672 that there actually is no inconsistency between Phil. XIII on the one hand, and I and IX on the other hand. This he proposed on the basis that the Greek underlying the Latin phrase qui cum eo sunt ("those who are with him") at the end of Phil. XIII,

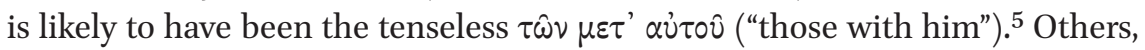
such as F.C. Baur in 1848 and A. Hilgenfeld in 1853, were early proclaimers of the view that the entire epistle is likely to be a forgery - one allegedly created by proto-orthodox Christian communities for the purpose of authorising the letters of Ignatius referred to in Phil. XIII.2. ${ }^{6}$

In the scholarly controversies surrounding Pol. Phil., a milestone was reached in the 1930s, when P.N. Harrison suggested that the apparent contradictions in the Polycarpian text might best be explained by its conflation of two separate letters - both of which would have been written by Polycarp himself, albeit at different times: the one before and the other after the death

4 See J. Daillé, De scriptis quae sub Dionysii Areopagitae et Ignatii Antiocheni nominibus circumferuntur (Geneva: Ioannis Antonii \& Samuelis de Tournes. 1666) 429.

5 J. Pearson 1672, Vindiciae epistolarum S. Ignatii. (Cambridge: Joann. Hayes. 1672) 72. It should be noted, however, that the emendation suggested by Pearson would - if it were accepted only dissolve the discrepancy as far as the author's knowledge of Ignatius' death goes. The inconsistency between, on the one hand the more definite knowledge regarding the fate of Polycarp expressed in Phil. I and IX, and on the other hand the request of information regarding Polycarp and his companions expressed in Phil. xIII, would still remain.

6 See F.C. Baur, Die ignatischen Briefe und ihr neuester Kritiker: Eine Streitschrift gegen Herrn Bunsen (Tübingen: Ludwig Friedrich Fues. 1848) 96, and A. Hilgenfeld 1853, Die Apostolischen Väter: Untersuchungen über Inhalt und Ursprung der unter ihrem Namen erhaltenen Schriften. (Halle: C.E.M. Pfeffer. 1853) 271-274. 
of Ignatius. ${ }^{7}$ In its simplicity, Harrison's theory is appealing, and in fact it had at one point become something of a default mode in modern scholarship on Polycarp. ${ }^{8}$ Nonetheless, sceptics have maintained that the Letter to the Philippians may very well be nothing but a fabrication created for the purpose of lending credit to the Ignatian letters it refers to - in which case the whole Ignatian corpus could also be approached as an example of 'frühchristliche Pseudepigraphie. ${ }^{9}$ There are still those, however, who remain confident that the letter forms a uniform and authentic whole - i.e., that the text as it has come down to us in fact approximates to an original letter written by Polycarp to the Philippian congregation. ${ }^{10}$

How, then, could one decide which of the four scholarly views outlined above is correct - i.e., whether the letter should be approached as fully inauthentic, as truly authentic and uniform, as a merger of two separate but authentic letters - or, as one authentic but interpolated letter? Considering the lengthy history of scholarly interest in this thorny and highly consequential question, one would surmise that all of the major issues have already been dealt with. All the same, in light of the textual-critical discussion as it has been conducted thus far, it is evident that one grammatical feature has not yet received proper attention - namely, the rare instance of a future participle

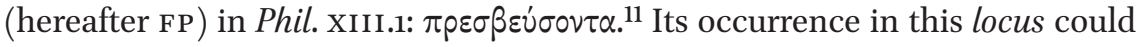
solidify the claim that the bulk of chapter XIII is an interpolation, assuming further that the scribe responsible for the interpolation was more prone to use the FP than Polycarp himself would have been. Before any such conclusions can be drawn, however, a more general examination of FPs in Ancient Greek needs to be conducted. Such an investigation is required especially with regard to the lower Judeo-Christian registers of late antiquity - i.e., the

7 P.N. Harrison, Polycarp's Two Epistles to the Philippians (Cambridge: Cambridge University Press. 1936) 15-19.

8 In the 1960s, L.W. Barnard even considered Harrison's theory to be "established beyond doubt". See L.W. Barnard, Studies in the Apostolic Fathers and Their Background (New York: Schocken Books. 1966) 39. For a reappraisal of Harrison's theory, see B.D. Ehrman, The Apostolic Fathers, Vol. I (London: Harvard University Press. 2003) 328-329.

9 T.J. Bauer \& P. Möllendorf, "Einführung", in: T.J. Möllendorf and P. Möllendorf (eds.), Die Briefe des Ignatios von Antiochia: Motive, Strategien, Kontexte (Boston and Berlin: De Gruyter. 2018) 6.

10 See P.A. Hartog, Polycarp and the New Testament: The Occasion, Rhetoric, Theme and Unity of the Epistle to the Philippians and its Allusion to New Testament Literature, Vol. I (PhD diss. Loyola University Chicago. 218) 232ff, and W.R. Schoedel, "Polycarp's Witness to Ignatius of Antioch", VChr 41.1 (1987) 1-10.

11 An active masculine accusative form in the singular of the verb $\pi \rho \varepsilon \sigma \beta \varepsilon v \dot{\omega} \omega$, which here means 'to send as a messenger'. 
colloquial Greek koine in which the texts included in the Apostolic Fathers were authored.

\section{$2 \quad$ Statistical Analysis}

In what follows, we present an analysis conducted for the exact purpose of determining the frequency and use of FPs in Ancient Greek literary sources. ${ }^{12}$

\subsection{Aims of the Analysis}

The guiding questions of our analysis are the following: (1) What is the frequency of F Ps in a large selection of Greek texts and authors from the Classical period to the beginnings of the 4th century $\mathrm{CE}$ ? (2) What differences in frequency can be discerned between different periods? (3) What are the implications of questions 1-2 for the text-critical question of Phil. XIII?

\subsection{Method}

In order to answer questions $1-2$, a corpus-linguistic method is necessary. This will hereafter be referred to as "statistical analysis". By using the search functions in the databases Perseus under PhiloLogic ${ }^{13}$ (hereafter Perseus) and Thesaurus Linguae Graecae ${ }^{14}$ (hereafter TLG), it is possible to track a particular grammatical category in very large quantities of texts. Thus, we have chosen these databases as our main research tools for providing us with the data for our analysis.

\subsection{Reliability of Data}

The main uncertainty we had with using Perseus and the TLG for our analysis was their ability to provide us with accurate data. Because of this, we crossreferenced the results from both databases for the full corpuses of Plato and Xenophon. We could then note that the TLG includes instances of FPs that Perseus has missed. However, in three cases we saw that the TLG made mistakes of its own. The omissions made by Perseus, on the other hand, are rather inconsequential: 11 out of 743 occurrences in total for the texts of Plato and Xenophon. The TLG thus includes both more incorrect FPs as well as a larger number of correct ones, whereas Perseus has a lesser degree of erroneous

12 The full presentation of the statistical data is to be found in the two appendices in V. Johansson, The Ancient Greek Future Participle and Polycarp's Epistle to the Philippians. A Statistical and Morphosyntactical Study (BA thesis, University of Gothenburg, 2020), available online via GUPEA.

13 http://perseus.uchicago.edu/Greek.html.

14 http://stephanus-tlg-uci-edu.ezproxy.ub.gu.se/index.php. 
listings but overlooks more instances of genuine FPs. In the final analysis, however, the inaccuracy of the databases was deemed by us negligible, and as not forming an insurmountable obstacle for the purpose of this study. ${ }^{15}$

\subsection{Unit of Frequency and Periodization}

The unit of frequency chosen for the here conducted statistical analysis is 'number of instances per 10,00o' words. Thus whenever we write 'frequency', this should be understood as 'frequency of F Ps per 10,000 words'. A reference like '(1,554: $3: 19.31)$ ' should be interpreted as "word count: number of FPs: frequency of FPs per 10,000 words". Of these, the first and third format $((1,554)$ and (19.31)) can also be used independently to stand for word count and frequency respectively.

Moreover, we have divided the material according to periods, linguistic style and genre - by way of the following division: 1) Classical, 2) Hellenistic, 3) Imperial, 4) Early low-register Judeo-Christian texts and 5) the Church Fathers and Writers of the Second Sophistic. There is no uniform employment of these classifications among classical philologists. However, in this study "Classical" refers to texts written prior to ca. 300 вСE, "Hellenistic" to texts prior to 3 о вС Е and "Imperial" to subsequent texts. Early low-register Judeo-Christian texts (included in this category are here the Septuagint (LXX), the New Testament (NT), the Apostolic Fathers (AF) and early Apocrypha, Hagiographa and Pseudepigrapha (AHP)) span over the Hellenistic and Imperial eras. The texts of the Church Fathers and Writers of the Second Sophistic, however, are encountered only from ca. the middle of the 2nd century CE.

\subsection{Classical Texts}

As an introductory remark to this section, we ought to comment on the basic fact that there is a wide range of frequencies (of F Ps) between individual texts. Considering Xenophon alone, we may note, e.g., that Anabasis has a frequency of 20.30 occurrences of F Ps per 10,000 words, whereas Apology of Socrates does not include a single FP. Between these two texts, however, the word counts also differ significantly - 57,142 to 2,000 - and this, of course, explains the difference with regard to instances of FPs as well. No other Xenophontean work is as short as the Apology of Socrates, and the next-shortest texts, Ways and Means $(3,853)$, Constitution of the Lacedaemonians $(4,925)$, On the Cavalry Commander

\footnotetext{
15 We have paid no heed to textual variation in our statistical analysis. The data is based on the text as it stands in the provided editions of the databases alone, and searches conducted in the apparatus critici are not available. This means that any conjectural emendation or highly suspect passage will be included, as long as the printed edition at the basis of the databases have them.
} 
$(5,781)$ and Hiero $(5,969)$, all exhibit instances, but with a significant difference in frequency: $10.38,4.06,13.84$ and 3.35 respectively. Cyropaedia, on the other hand, is even longer than Anabasis $(79,291$ to 57,142$)$ but displays a lower frequency (13.12 to 20.30).

Moving on to Plato, we encounter a similar variation: Lovers $(2,395)$ has no occurrences of FPS whatsoever, while Cleitophon $(1,554: 3$ : 19.31) has a frequency comparable to that of Anabasis. This should caution us to deduce any strict correlation between high word count and high frequency; small texts could display a low frequency or a high frequency and substantial texts could display a low frequency or a high frequency. Overall for Xenophon and Plato, the frequency of individual texts ranges between $o$ and slightly over 20 and everything in between.

Turning the attention to variations in frequency between individual texts by other classical authors, we can see that Aeschylus ranges between $o$ and 13.48, Euripides between 3.68 and 25.84, Aristophanes between o and 19.46, Aristotle between $o$ and 11.59 and Hippocrates between $o$ and 21.10. Sophocles is the only author displaying a constant pattern, lying steadily between 13.78 and 10.11. However, when scrutinizing the total frequency of individual authors and collections, the numbers become more uniform. Only five authors have a frequency much below 10 (among them Plato with a frequency of 6.09), and the rest are ranging between ca. 10 to 14 (e.g. Xenophon has 12.85). Thucydides and Dinarchus are exceptions, however, as they show unusually high frequencies: 17.05 and 19.81 respectively.

\subsection{Hellenistic Texts}

Of authors in this period, the lengthy texts of Polybius $(310,672)$ and Diodorus Siculus $(191,772)$ fit in neatly with the majority of the Attic authors - with the frequency of Polybius (15.42) being quite close to that of Thucydides (17.05) (whereas Diodorus' is somewhat lower: 11.99). When considering individual texts in this era, it may be noted that the frequency of Theophrastus' Characters (21.05) is rather high, but nothing out of the ordinary; cf. Anabasis (20.30), Menexenus (20.78), Rhesus (25.84), Exordia (22.08) and Prognostics (21.10). Callimachus (10.76) also accords with the general Attic trend, while Apollonius Rhodius (5.41) is closer to the lower end of the spectrum.

\subsection{Imperial Texts}

When focusing on individual texts in this period, the Greek literature of the Roman Empire seem to exhibit a similar tendency with regard to variations in frequencies of FPs as the literature of the Classical and Hellenistic period. For example, Aethiopica $(76,350)$ by Heliodorus and The Civil Wars $(116,909)$ 
by Appian show high frequencies (22.92 and 25.23), whereas the frequencies of texts such as Legum allegoriarum libri i-iii $(31,865)$ by Philo and Historia Indica $(13,942)$ by Arrian are much lower (1.26 and 3.59 respectively). What is noteworthy is that it is in this period that we found the examples of texts with the highest frequencies: Life of Flavius of Josephus $(15,706)$ and Appian's Concerning Italy $(1,080)$; with frequencies of 43.93 and 64.81 respectively (the extremely high frequency of the latter text may be explained by its unusually low word count).

When considering individual authors in this era, however, the differences in frequency between authors turn out to be considerably more conspicuous than in the Classical era. At the bottom end, we find Galen (31,741: 2.21), Strabo (146,495: 2.73), Diogenes Laertius (109,039: 3.67), Chariton (34,966: 3.72) and Apollodorus (35,162: 4.55). At the top, we have Flavius Josephus (464,781: 23.86), Heliodorus (76,350: 22.92) and Appian (222,309: 21.14). Manifestly, there is thus much more variation in frequencies in the use of FPs between authors in the Imperial period than in the Classical era.

\subsection{Early Low-Register Judeo-Christian Texts}

With the translation of the LXX - which could of course also be classified as belonging to the texts of the Hellenistic and Imperial periods - the frequency of FPs drops to unprecedented levels. This large collection, with a word count of ca. 587,700, exhibits a mere 66 cases, which gives a frequency of 1.12. A closer inspection of the distribution between the individual texts reveals that the occurrences are confined particularly to Maccabees I-IV (27), Psalms (6), Ecclesiastes (5), Sirach (4), Jeremiah (4) and Isaiah (3). These occurrences stand for 49 out of a total 66 . Moreover, 14 texts within the Lxx contain one or two FPs, whilst the vast majority contain none.

The authors of the NT display the same reluctance to use FPs as we just saw in relation to the LXx. With a total word count of ca. 137,900, and a total count of a mere 13 FPs, the frequency here is even lower than that of the LXX: 0.94. Of individual texts in the NT, only Acts and Hebrews contain more than one case (five and two respectively). Of course, in contrast to the LXX, we are dealing here with texts composed (at least for the most part) originally in Greek. It is therefore noteworthy indeed that these texts show roughly the same frequency despite this fundamental difference in origin. Consequently, the lack of FPS in the LXX cannot simply be due to the nature of the language translated (and a literalistic approach to translation). Given the attestation of the same lack of FPS in the NT - and, as we shall see, in other corpora employing the same language - this absence must be considered a distinct feature of the Greek employed. 
Moving on to the AF, we may observe that the frequency is dropping even lower. The total word count of 63,314 in this corpus is decisively lower than that of both the LXX and the NT. However, with the whole AF exhibiting a mere $4 \mathrm{FPS}$, the frequency of 0.63 in this corpus is the lowest one yet. We must of course approach such a relatively minor assemblage of texts with some caution, but the data is perfectly in line with that of the LXX and the NT.

In case of the AHP, the frequency is also in accordance with the LXX, the NT as well as the AF: the total frequency of the AHP is 1.38, which is much below the corpora of earlier times. Since many of the texts included in the AHP are minor, e.g., Assumptio Mosis (404: 1: 24.75), the relatively high frequency generated in these cases (if one or two FPs occur) should not be given undue weight; this would simply be the nature of a corpus with numerous small texts.

\subsection{Church Fathers and Writers of the Second Sophistic}

The Church Fathers and Writers of the Second Sophistic, lastly, interrupt the pattern established in the last four collections dealt with above by returning to levels more in line with other Imperial authors. At the bottom end of frequencies, we find Irenaeus (36,891: 2.71), who could be compared with Diogenes Laertius (3.67). At the top, we find Origen (512,887: 9.53), whose frequency is close to that of Dio Chrysostom (9.09). Further, we find here also Flavius Philostratus (10.45) and Philo (8.48) (all three of these high-frequency authors have sizeable amounts of text $(179,346,151,243$ and 422,221)). Frequencies closer to 20 are nonetheless absent among these texts, leaving the top Imperial authors unsurpassed in this regard. In this connection, a cautionary note is, however, necessary: large chunks of the texts of the Church Fathers consist of citations of earlier texts. In particular, this would be the case with regard to Eusebius (831,674: 624: 7,50), who quotes earlier Greek texts extensively.

When studying the individual texts of the Church Fathers and Writers of the Second Sophistic, we may observe similar variations in frequencies as in the Classical and Imperial periods: from o up to 24.11 and everything in between. However, among these writings, we encounter no larger text without a single occurrence of a FP - in profound contrast to what we just saw in connection with the early low-register Judeo-Christian texts. Several of the texts exhibiting high frequencies in this part of the material are, however, rather small, making their high frequencies difficult to compare with earlier - more substantial - texts (although Apologia prima pro Christianis ad Antoninum Pium (14,508: 19.99) and De oratione (27,945: 16.82) could perhaps be taken as instances of substantial texts exhibiting a high frequency of FPS).

As were the authors in the AF, the Church Fathers were also well acquainted with the LXX and the NT. In contrast to the Apostolic Fathers, however, they never adopted the language of their sacred texts. Instead, they opted for writing 
their texts in a more or less Atticist Greek style. Indeed, the relatively high frequencies of FPS in the texts of the Church fathers can be viewed as a marker of their Atticising tendencies.

The consideration of the texts of the Church Fathers and the Writers of the Second Sophistic complete our statistical analysis. In what follows, we summarise its findings.

\subsection{Summary}

The above analysis has clearly demonstrated that in the Classical period, substantial variation in the frequencies of FPs between individual texts is the norm. The frequencies for individual authors/collections, on the other hand, are more consistent. Hellenistic texts, as far as we can see, fit into the classical pattern. The frequencies in individual Imperial texts vary greatly as well, but here the same rule can be seen to apply also to individual authors - which was not the case in earlier periods. Early low-register Judeo-Christian texts, again, generally make only scant use of the FP, whereas the somewhat later Church Fathers and Writers of the Second Sophistic align more closely with the Imperial authors apart from the Judeo-Christian texts and do exhibit FPS.

In comparison with the Greek of the classical period, the low-register Judeo-Christian texts we have examined - i.e., the LXX, NT, AF and AHP clearly stand apart with regard to their sparse employment of the FP. When inspecting texts from the Hellenistic and/or Imperial era, on the other hand, the data show that there are major fluctuations between different corpora. However, the frequencies of FPs in low-register Judeo-Christian texts still constitute the lowest end of the spectrum compared to any other genre, era and style of Ancient Greek literature. ${ }^{16}$ Of course, it is true that FPs do appear sporadically in the Judeo-Christian texts as well, and that any instance of a FP - in and by itself - should not constitute sufficient reason for emendation. However, we contend that in an already disputed passage, the discovery of a FP most certainly could warrant emendation. Because - in this genre and style of Greek literature - the occurrence of a FP is a linguistic peculiarity, and as such should be taken into account in any textual-critical discussion.

The terminus ante quem for when a F P may have been interpolated into Phil. XIII is the first few decades of the 4th century - since this is when Eusebius

16 We exclude here epigraphic and papyri material from the comparison, since we have only examined literary texts. 
quoted the passage (including the FP) in his Historia ecclesiastica (III.36.1415). If we are to assume, then, that the Polycarpian passage containing the FP truly is an interpolation, we must assume as well that someone had inserted the forgery into the text before the close of the 3 rd century. Furthermore, the false copy must then have been distributed widely enough for Eusebius to have had access to it when he wrote his history. If this hypothetical interpolator had any Atticising tendencies - as was indeed the case for many Christian theologians writing after the AF - the inclusion of a FP in his forgery would not be remarkable.

Of course, one may still ask why he would insert such a form - a common feature only in Attic Greek and higher literary koine - into a linguistic milieu so clearly devoid of higher Attic pretensions. Perhaps this ambiguity just did not occur to the scribe at the moment of composition, or perhaps the scribe felt that there was no problem with embellishing Polycarp with a higher register of language. We can only speculate as to the scribe's thoughts on the matter. The indisputable fact remains, however, that ancient forgeries were not always very successful in imitating the style and language of their target texts. ${ }^{17}$

What about the much-discussed question, then, if the alleged interpolation of chapter XIII may have been connected to a desire for authenticating a forged Ignatian corpus? This possibility has been suggested, inter alios, by J. Turmel who proposed that Phil. XIII was interpolated by an early editor of the letters ascribed to Ignatius sometime in the late 2 nd century. Moreover, Turmel also assumed that the editor in question was the first to ascribe the Ignatian letters to the martyr Ignatius from Antioch; originally they had been composed by a Marcionite bishop with the same nickname as Ignatius, - Theophorus. ${ }^{18}$ However, our analysis suggests that it is inconsistent to equate the forger of the Ignatian corpus with the forger of Phil. XIII. If the linguistic disposition of the forger of Phil. XIII had made him prone to insert a rare grammatical

17 A classic example of the phenomenon in question is the disputed ending of Mark. The Greek text tradition includes three apparently inauthentic endings to this text. Of these, the so-called 'longer ending of Mark' is the "traditional" version - i.e., the version included in Erasmus' early printed edition and in countless subsequent translations. This longer ending contains, however, language highly untypical for Mark. This internal proof, together with additional external evidence, leaves little room for doubt that the reading in question is secondary: see B. Metzger \& B.D. Ehrman, The Text of the New Testament: Its Transmission, Corruption and Restoration, 4 th ed. (Oxford: Oxford University Press. 2005) $322-327$. In comparison with Phil., what is most noteworthy in Mark is that the longer ending clearly forms an interpolation, and that the interpolator was unsuccessful in imitating the target text.

18 See J. Turmel "Nouvel examen des lettres d'Ignace d'Antioche", Revue d'histoire et de littérature religieuses 8 (1922) 303-337. 
feature that was highly inappropriate for the target text, then we should expect the phenomenon to reoccur in connection with the forging of the Ignatian epistles - if indeed it was the same person forging the latter corpus as well. ${ }^{19}$ The letters ascribed to Ignatius, however, do not include a single FP.

Perhaps it was so, then, that the forger purposely avoided the use of FPs in the Ignatian corpus, but disregarded this detail when forging Phil. XIII? However, if he consciously avoided FPs when forging the letters ascribed to Ignatius, this would prove that the forger was in fact aware of the unseemliness of the FP in this literary context. That he would not then operate with the same level of exactness when interpolating Phil. XIII - given that the texts of Ignatius and Polycarp are linguistically similar - strikes us as incredible. This leads us to conclude - contra Turmel and others - that the forger of Phil. XIII most likely was not directly connected to the alleged forger (or editor) of the Ignatian epistles. The possibility still remains, of course, that it was exactly the desire to strengthen the appearance of authenticity in the collection of letters ascribed to Ignatius - if indeed these letters are fabricated - that stood as a motivation for whoever actually interpolated Pol. Phil. ${ }^{20}$ However, it is also possible that the bulk of Pol. Phil., as well as parts or whole of the Ignatian corpus, are both genuine - whereas Phil. XIII is an interpolation.

In the above analysis, we have emphasized that the FP is an exceedingly rare phenomenon in low-register Judeo-Christian Greek texts in general, and in the AF in particular - and that therefore its singular occurrence in Pol. Phil. should raise suspicions as to the authenticity of the passage in which it occurs. However, it must be acknowledged that FPs do occasionally occur in low-register Judeo-Christian texts, and that there is - and always has been - a significant level of variation at the micro-level, i.e., between individual texts within a corpus with regard to frequencies of FPs. The possibility thus remains that Phil. XIII forms one of those rare cases, where a FP does occur naturally in

19 Especially considering that the seven letters of Ignatius have a word count closer to 8,ooo, the forger would have been expected to have used FPs at least a few times over the course of fabricating these epistles. Indeed, to assume anything else would not be in line with what we may deduce from our statistical analysis - since all authors we have examined, except for the ones writing in a low-register tone of koine Greek, can be seen to exhibit a frequency of F Ps higher than 3 per 10,000 words.

$20 \quad$ A theory to this effect was actually propounded by R. Joly in the 1970s. Joly hypothesized that the bulk of the Ignatian letters and the Martyrdom of Polycarp had both been written at Smyrna shortly after Polycarp's death (ca. 16o CE), and that it was here as well that the (otherwise genuine) Polycarpian letter was first interpolated - since "c'est évidemment à Smyrne en tout premier lieu qu'on pouvait attacher de l'importance au témoignage de Polycarpe". See R. Joly, Le dossier d'Ignace d'Antioche (Bruxelles: Editions de l'Université de Bruxelles. 1979) 115 . 
an author who normally would not use it. However, as our analysis has shown, this would certainly be an odd happening.

\section{Conclusion: the Letter of Polycarp}

This study set out to statistically analyse the frequencies of FPs (future participles) from Attic Greek to the beginning of the 4th century CE. The ultimate goal of this analysis was to contextualise the singular occurrence of a FP in Polycarp's Letter to the Philippians. The purpose of this contextualising, in turn, was that of illuminating the text-critical issues revolving around Pol. Phil. XIII. Our study was conducted with the use of two digital databases: TLG and Perseus under PhiloLogic. From these, data have been culled, analysed and applied to Phil. XIII. General patterns of usage have been observed in the analysis, and - most importantly - the frequencies of FPs in early low-register Judeo-Christian texts have been shown to lie much below all other ancient Greek literary texts.

We are thus in a position to conclude this paper by stating the consequences of our analysis regarding the four main strands that can be identified in the scholarship on the question of the unity and authenticity of the Polycarpian letter. Should the Letter to the Philippians be approached as fully inauthentic, as truly authentic and uniform, as a merger of two separate but authentic letters - or, as one authentic but interpolated letter? As may be readily understood, our analysis clearly supports the fourth scholarly view, initiated by J. Daillé in 1666, which approaches the Polycarpian letter as a unified piece of writing, composed by the hand of a single author - which author may very well have been the early Christian martyr Polycarp of Smyrna. However, just as was recognized by Daillé, our analysis also supports the view that the bulk of chapter XIII is likely to be a spurious interpolation. Moreover, the statistics on FPs in Ancient Greek texts we have gathered indicate that the scribe who interpolated the FP in Polycarp is likely to not have been identical with the alleged forger of the Ignatian letters.

Our contribution to the scholarship on Polycarp's Letter to the Philippians may thus be seen to boil down to the discovery and analysis of the most relevant linguistic evidence supporting the view that chapter XIII is a false addition to an otherwise uniform and authentic letter: the odd future participle

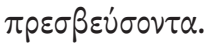

